organisation. A resistance-capacitance beat-frequency oscillator covering the range $0-5,000$ cycles per second is described by D. S. Robertson and L. C. Nye, certain features underlying the design having been developed theoretically in another paper by L. E. V. Lynch and D. S. Robertson. A description is also given by L. G. Alexander of an equal-ratio impedance bridge by means of which impedances can be measured to a precision of 1 per cent or better at frequencies up to $3 \mathrm{Mc} . / \mathrm{s}$.; while two specialpurpose receivers covering the range of frequencies from $50 \mathrm{kc} . / \mathrm{s}$. to $50 \mathrm{Mc} . / \mathrm{s}$. are described by B. Sandel. In a paper entitled "Directional Patterns of Rhombic Antennæ", W. N. Christiansen examines the spatial radiation patterns of typical rhombic antennæ in relation to that of a large tuned array, to which a single rhombic is inferior. After discussing various simple designs, the author shows that it is possible to arrange several rhombics in the form of an inter. laced 'end-on' array so as to produce over the whole frequency range of the rhombic aerials a directional radiation characteristic which compares well with that of a tuned array at its single designed frequency. Other papers in this issue deal with such subjects as the application of a Geiger counter for determining the thorium content in wire used in valve manufacture, a radio-frequency form of high-tension supply for cathode-ray tubes, and a vacuum-sealed relay designed for operation with aircraft aerials transmitting at high voltages.

\section{Bacteriology in the Kitchen}

AN interesting article by Dr. Irene Hutchinson (Brit. Med.J., 134, Jan. 25, 1947) directs attention to the unsatisfactory methods employed in many communal feeding centres for the cleaning of utensils used for eating. In a London dormitory town in which food inspection was kept at a very high level, unannounced visits were made to twenty-five kitchens of hotels, restaurants of multiple stores, day-nursery kitchens, teashops, snack bars and a civic restaurant. Samples of washing-up water in actual use were taken at the peak hour between 12.30 and 1.30 p.m., when conditions were at their worst, and swabs were taken from spoons, cups, forks, glasses and plates which had been used and washed and were ready to be used again. The organisms obtained from these sources are listed, and Dr. Hutchinson concludes that the cleaning of eating utensils is "very unsatisfactory, and that pathogenic organisms are likely to be spread by the users of different articles". The lack of washing machines, the difficulty of getting soap and washing powders and the scarcity of drying towels make it very difficult to feed people hygienically. In one only of the twenty-five kitchens were dysentery bacilli found on spoons, and Dr. Hutchinson comments that this "may suggest the origin of the sporadic case of "diarrhœa",. Other findings of pathogenic staphylococci may help to explain the high incidence of septic mouth lesions so common during recent years. The proprietors of the various premises visited showed great interest in the work and helped it in every way that they could. An annotation in the same issue of the British Medical Journal (p. 143) critically discusses the results obtained, and suggests that the greatest need is for education of the people who handle food. In the United States much progress has been made in this matter, and in Great Britain the Central Council for Health Education is arranging courses of instruction on food hygiene for food handlers (Health
Educ. J., January, 1947, p. 11). Facilities for dishwashing and for the cold storage of food, says the annotation, need to be greatly improved. Few people will disagree with this conclusion. It may be compared with the need for the adequate treatment and care of milk bottles which was discussed in Nature (153, 31 ; 1944).

\section{Agriculture in Malaya}

AfTer a break of five years, the Malayan Agricultural Journal has reappeared, though for 1947 it will be published as a quarterly only. Vol. 30, No. 1, contains a message from the governor of the Malayan Union, Sir Edward Gent, and a foreword from the Director of Agriculture. The Department was fortunate in being able to resume active work through its field branch shortly after the liberation of Malaya, the staff being now almost back to pre-war strength. Food production and general rehabilitation have been its chief immediate concern, but long-range plans are already under consideration. These include the establishment of a Central Government Fruit Experiment Station, the rehabilitation of rubber smallholdings of high-yielding clonal material, canning and food preservation, the expansion of the School of Agriculture at Serdang, and development of the livestock industry. Among the original articles in this number is an account of intensive gardening in a prisoner-of-war camp which cannot fail to be of interest to all readers.

\section{'Positex'}

AN 8-page pamphlet, 'Positex' Pamphlet No. 2 , published by the British Rubber Development Board, 19 Fenchurch Street, E.C.3, and written by Dr. C. M. Blow, deals with the compounding, pigmenting and thickening of 'Positex', a form of rubber latex in which the particles carry a reversed or positive charge. There are also some notes on the removal of rubber from fibrous materials. The research work referred to in the pamphlet was carried out by the Wool Industries Research Association, in collaboration with the Technical Research and Development of New Uses Committee of the Rubber Growers' Association, and later with the British Rubber Producers' Research Association. The introductory pamphlet to the series gave a general account of the material and of its possible commercial applications. Licensees for 'Positex' in Great Britain are Messrs. Revertex, Ltd., King William Street House, Arthur Street, London, E.C.4, and Messrs. Veedip, Ltd., St. Helens Works, Slough.

\section{Engineering Degree Courses for Ex-Servicemen}

Mr. O. S. Puckle, of R. F. Equipment, Ltd., Langley Park, Nr. Slough, Bucks, recently invited inquiries from engineers and others wishing to study for science and engineering degrees (Nature; April 12, p. 497). He now states that he has received a total to date of ninety-three completed questionnaires. Of these, fifty-one are from the London area, including Dartford and south-west Essex, and ten from Stokeon-Trent. The numbers in each of the other localities are too small to make it possible to ask the Ministry of Education to take action; but it is hoped that in London and Stoke it may be possible to arrange the suggested courses. $\mathrm{He}$ is communicating with the Ministry of Education, to whom the questionnaires and an analysis of the results are being sent. Those who have not yet returned the questionnaires for 
which they asked should do so immediately, especially if they wish to take courses in the London area or in Stoke.

\section{Conference on Infestation of Stored Foodstuffs}

The Food and Agriculture Organisation of the United Nations has invited its forty-seven member Governments to send experts to meet in London during August 5-12, for a conference on the problems of infestation of stored foodstuffs. This term includes food undergoing transit, storage and processing. Problems to be studied include measures to prevent infestation such as adequate improved warehousing facilities, as well as a study of methods of pest control used in the various countries. Also to be investigated are world foci of infestation and the channels through which insects, mites, rodents and mould fungi are carried in foodstuffs to all parts of the world. Aspects of the production, availability, and consumption of insecticides, fungicides, fumigants and rodent poisons will also be examined. An attempt will be made to obtain some idea of the extent of the very grave losses which are known to occur through infestation, and to recommend measures which could be applied to prevent these losses. A report of the recommendations of the meetings will be submitted by the Food and Agriculture Organisation to all member Governments and to other interested international agencies.

\section{Congress of the Universities of the British Empire}

IT is announced that, at the invitation of the University of Oxford, the next Congress of the Universities of the Empire will be held in Oxford during July 19-23, 1948. The Universities Bureau of the British Empire is requesting each of its member institutions to appoint four delegates, and although present conditions have necessitated this limitation of numbers, it is expected that about three hundred senior teaching and administrative officers will attend as representatives of universities and other institutions of higher learning, both home and overseas. The subjects for discussion at the various sessions will be announced later.

There have been five previous congresses, the first having been held in London in 1912 as the result of a resolution adopted by the Senate of the University of London in 1909. All the universities of the Empire sent delegates to that meeting, when it was agreed to establish the Universities Bureau in London and to hold congresses regularly every five years for the discussion of questions of academic policy of common interest. The two World Wars have interrupted this quinquennial programme of meetings; but congresses were held in 1921 (at Oxford), 1926 (at Cambridge), 1931 (at Edinburgh), and 1936 (at Cambridge). The 1948 gathering will therefore be the first general meeting for twelve years of official representatives of the universities of the British Commonwealth and Empire.

\section{University of Glasgow: Chair of Physiological Chemistry}

Prof. James Norman Davidson has been appointed to the Gardiner chair of physiological chemistry in succession to Prof. G. M. Wishart. Prof. Davidson graduated in chemistry at Edinburgh in 1934, and later took the degrees of M.D. (1939) and D.Sc. (1945). During 1937-38 he worked with
Warburg at the Kaiser Wilhelm Institute for Cell Physiology. He has held lectureships in biochemistry at Dundee and St. Andrews; has been on the scientific staff of the Medical Research Council ; and for the past year has been professor of biochemistry at St. Thomas' Hospital Medical School, London (see Nature, 157, 760 ; 1946). His research work touches on many fields, including those of carbohydrate metabolism and of the nucleic acids.

\section{Announcements}

Sir Alexander Fleming and Sir Howard Florey have each been awarded the Gold Medal of the Royal Society of Medicine for their work on penicillin. The Medal is normally given once in three years, but on this occasion two were awarded.

Dr. John H. Lawrence, of the University of California, will deliver the twenty-fourth Mackenzie Davidson Memorial Lecture at the British Institute of Radiology on July 17, at 8 p.m., in the Reid-Knox Hall, 32 Welbeck Street, W.1. He will speak on "The Application of Artificial Radioactivity to Biology and Medicine".

Mr. Harold Claughton is retiring from the post of principal of the University of London on December 31 , and the Senate, with the concurrence of the Court, has appointed Dr. D. W. Logan, clerk of the University Court since 1944, to succeed him.

Aт the University of Aberdeen on July 3 the honorary degree of LL.D. was conferred on Prof. C. D. Broad, Knightsbridge professor of moral philosophy in the University of Cambridge. Among other degrees conferred was that of Ph.D. on K. Hassan for a thesis on "Factors affecting the Utilization of Phosphorus in the form of Phytic Acid by the Ruminants" ; and M.D. on L. D. M. Gavin for a thesis on "The Military Malaria Campaign in Greece, 1945".

THE following elections to the Paris Academy of Sciences have been announced: M. Pierre Teilhard de Chardin, Gaston Delépine, of Lille, and Prof. Pierre Pruvost, professor of geology and mineralogy in the University of Lille, correspondants for the Section of Mineralogy ; Prof. H. A. Kramers, professor of mathematical physics in the University of Leyden, and Prof. René de Mallemann, professor of physics in the University of Nancy, correspondants for the Section of General Physics; Prof. Emile Briner, professor of theoretical and technical chemistry in the University of Geneva, Dr. C. H. Desch, honorary scientific adviser to the Iron and Steel Research Council, and Prof. Hans von Euler, professor of chemistry in the Stockholms Högskola, correspondants for the Section of Chemistry.

Mr. G. F. Cole, who for the past year has acted as assistant secretary of the Illuminating Engineering Society, has now been appointed secretary of the Society.

THE following appointments have been made in the Colonial Service: A. B. Cahusac, assistant conservator of forests, Uganda; M. S. Philip, assistant conservator of forests, Uganda; A. C. M. McKinlay, geologist, Tanganyika Territory; R. K. J. Gascoigne (agricultural officer, Nigeria), entomologist, East African Anti-Locust Directorate, Kenya. 